\title{
Experiences with the Design and Production of an Industrial, Flexible and Demountable (IFD) Building System
}

\author{
Frans van Gassel * \\ Eindhoven University of Technology, Department of Architecture, Building and Planning, \\ P.O. Box 513, 5600 MB Eindhoven, The Netherlands.
}

\begin{abstract}
The Dutch government encourages innovative construction by subsidizing cohesive industrial, flexible and demountable building (IFD) pilot projects. Industrial building concerns the process-related aspects of production, robotization, mechanization, automation, prefabrication, communication, etc. Flexible building involves products that are made in accordance with customer's wishes and the possibility to make adjustments when the building is in use. Finally, demountable refers to the sustainability of the building.
\end{abstract}

This paper describes the experiences relating to the design and production of a demonstration project (IFD Today) for an apartment building system on the Eindhoven University of Technology campus. A housing corporation had commissioned the design of an industrial, flexible and demountable building system for flats, on an existing foundation, the surface area and floor plan of which had to be adaptable during use. The current flats do not meet present requirements as set by the government and the occupants, and renovation is too expensive. The data was obtained through participation in the design team and close production monitoring. The paper focuses on industrial building.

After monitoring the design and production process, the following conclusions can be drawn:

- IFD building requires co-operation and a multidisciplinary approach during the design process. Essential issues to be considered during the design process are the tasks, choice of designer, design tools and the expected result. Design meetings must also be organized.

- Due to the lack of a suitable model to calculate the production, operating, renovation and demounting costs and the absence of a marketing plan, conventional designing solutions were frequently applied.

- The steel structure and floor panels were mounted very quickly. This was in contrast to the outer walls, roof, fittings and finishing elements.

- It is advisable to entrust one specific company with the responsibility for a number of production tasks, such as planning, making and checking the drawings, and allocating labor resources with regard to transport and safety.

KEYWORDS: Building Site, Building System, Industrial Construction, Multidisciplinary Design.

\section{INTRODUCTION}

A trial module was built on the Eindhoven University of Technology campus to gain experience with the design and production of an IFD building system. This paper presents the findings. The first paragraphs explain the concept of IFD building, the IFD Today project and how the study was set up. Finally, conclusions and recommendations are made with regard to the marketing of the IFD building system, based on the results of the study.

\section{IFD BUILDING}

In the Netherlands, a program entitled 'Industrial, Flexible and Demountable Construction Demonstration Projects' has been developed by the Ministry of Economic Affairs and the Ministry of Housing, Spatial Planning and the Environment. This program was developed to promote the innovative application of industrially developed and manufactured construction components in the construction and renovation of homes and public utility buildings.

\footnotetext{
*E-mail: f.j.m.v.gassel@bwk.tue.nl
} 
IFD building provides an integrated approach to the initiation phase, the design, production and use of buildings, and is characterized by early co-operation between the parties, enabling alignment of the concept, design and execution. The industrial production of components offers increasing opportunities for flexible use. Demountable building enables a separate replacement of components with various lifespans, thereby extending the life of the building as a whole. As such, IFD building is a form of sustainable building. [SEV]

Van den Brand describes IFD building as a threepronged strategy to innovate the building process: the client (flexible), the manufacturer (industrial) and society (demountable). This is characterized by the following principles: 'level-thinking' [building - floor - room - work station], a fixed form and space combined with variable options for the interior, a multidisciplinary design, separate technical systems; dimensioning and nodes; modularity and demountability. [Van den Brand]

\section{IFD Today}

Between 1945 and 1963, about 400,000 apartment buildings were constructed in the Netherlands with the following characteristics: traditional design, the use of clay, no insulation, poor sound insulation. They were, almost without exception, four-storied staircase-access flats. Between 1964 and 1975, another 475,000 medium-rise apartment buildings and 300,000 high-rise apartment buildings were constructed. Today, these apartments still have poor (sound) insulation (see figure 1).

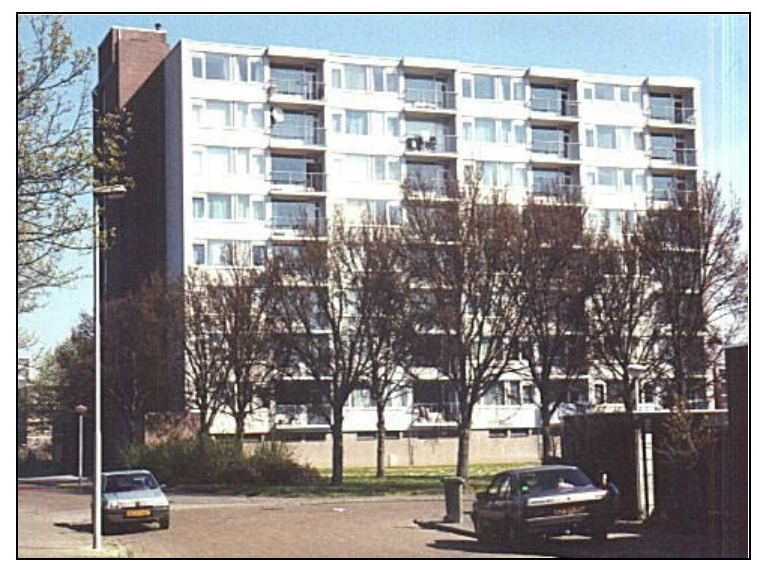

Figure 1. Apartment blocks.

The improvement of post-war houses as from 1974 mainly involved the application of insulation. Although heat insulation was improved, the number of problems associated with building physics increased. In spite of substantial investments, very little could be done to improve the living quality. Houses were cramped and inadequately equipped, they had poor sound insulation, and were only accessible by a narrow staircase.

A more drastic approach proved technically impossible or would have required substantial and unprofitable investments. The current demand for houses is very diverse in terms of surface, layout and fittings. Even in cases where a drastic approach was adopted, the required level of housing differentiation could not be achieved within the existing shells. For this reason, more and more post-war houses will be demolished. [IFD Today]

A partnership (IFD Today) between the Amnis housing corporation, contractor Heijmans IBC, installer Stork and the Eindhoven University of Technology has chosen to solve the above problem with IFD building. A design team comprising staff employed by the partners was instructed to develop an IFD building system using existing technology.

\section{IFD BUILDING SYSTEM}

According to Eekhout, a building system is an orderly collection of construction elements and construction components with connecting facilities, which can be combined or applied in various ways, in accordance with regulations or agreements and depending on the environment. [Eekhout]

The building system process is characterized by the following aspects: technology, the human factor, information and organization. The building system product is characterized by the aspects of function, flexibility, geometry, materials, structural and technical capacity, complexity and cost. The dominance of the aspects depends on the market in question. The production of frequently used construction elements has now largely been mechanized or is carried out by robots, for example. Specific construction elements requested by the client are manufactured in the traditional way.

The conceptual design in IFD building is based on six specific values of a building:

- Basic value: achieving a building physics level that is higher than current standards. 
- Use value: aiming for as much layout freedom as possible at building, story and apartment level and with regard to individually adjustable and quantifiable installations.

- Local value: achieving a building system that allows differentiation possibilities according to type, surface, layout, fittings and architecture.

- Ecological value: reusing foundations and the necessity of applying light structures.

- Economic value: developing a product in line with marketing conditions.

- Strategic values: constructing a building that can be adjusted in the course of time.

These values can be considered on four different levels: the built environment, building, house and living quarters level. The conceptual design addresses the design aspects, viz. the requirements, design, quantification and design strategy.

[Rutten] [Systeemcatalogus IFD Today]

Hendriks has developed a number of design criteria for IFD building:

- Integration and independence of disciplines: installation, bearing structure, outer shell and interior finishing.

- A completely dry building method: no pouring of concrete, mortar joints, screeds, stuccowork, sealant or PUR spray.

- Perfect modular dimensioning: a great deal of attention to drawings, prototype testing, quality system for drawings, and assembly instructions.

- Adjustability of all parts: bearing structure (limited), installation (practically unlimited), outer shell (limited and modular), interior finishing (practically unlimited and modular). [Hendriks 1999]

The IFD building system has the following characteristics:

- A steel support construction of hot-rolled standard profiles, L-supports at the corners, and I-supports and joists on the grid line.

- The supports provide stability and the joists have been fixed to the bearers in such a way that vibration is kept to a minimum. The floor panels are placed on the joists.

- The floor panels are hollow to enable the inclusion of technical installations. See figure 2.

- Piping can be placed in the supports and the floor panels at the plant or the building site.
- Non-bearing walls dividing houses and rooms can be placed anywhere.

- Free choice of outer wall.

- There is no specific roof design. The traditional solution is adopted, i.e. warm roof.

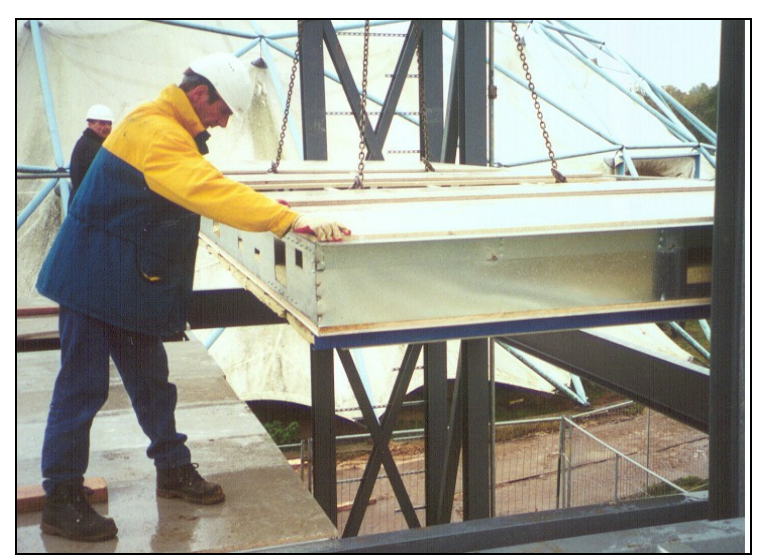

Figure 2. Assembling the floor panels.

Characteristic elements of IFD building are:

- An 11-meter span and a 7.2-meter grid.

- Optimal free space providing various layout possibilities.

- Maximum flexibility with respect to vertical and horizontal piping, providing various possible locations for toilets, kitchens and bathrooms.

[Systeemcatalogus IFD Today]

\section{STUDY}

To gain experience with the IFD building system, a trial module was built on the DUBO (Sustainable Building) park on the Eindhoven University of Technology campus. The trial module is fourteen meters wide and eleven meters deep, and has two stories. See figure 3.

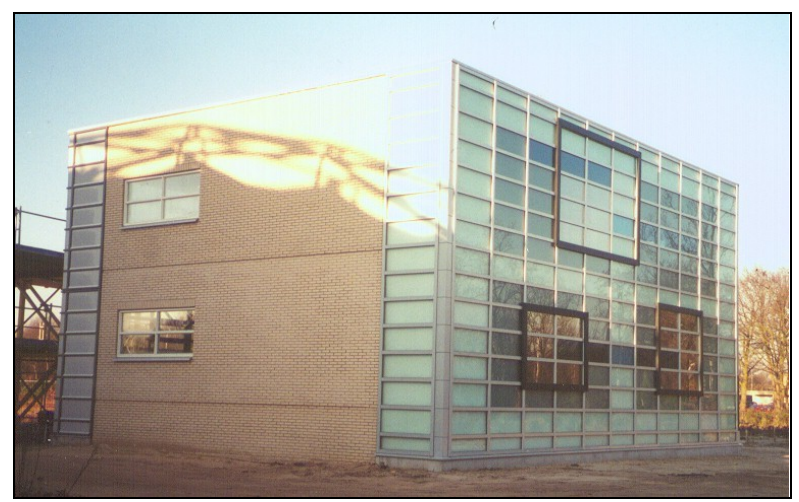

Figure 3. IFD building system trial module on the Eindhoven University of Technology campus. 
Not only the trial module's design process but also its production process was assessed for its IFD characteristics.

This report only describes one aspect of IFD building, viz. industrial building.

According to its conceivers, the IFD technology makes use of the following traditional elements of industrial building:

- Production at the plant.

- Mechanized production.

- Mass production.

- Co-operation is independent of projects.

- Deployment of information technology.

Today, the emphasis in industrial building is on:

- Customer-oriented production and marketing.

- Flexible production systems.

- Subsystems are independent but can be combined.

\section{[Hermans]}

The transfer of production from the building site to the plant has resulted in an integration of functions and sometimes materials of a component or a system of components. This requires a high level of component alignment (specifications, dimensioning, finishing) [Bouwen op kennis]

For the purposes of this study, the following description of industrial building is used: the transfer of physical tasks from the building site to the plant and from people to machines and computers. These tasks do not involve building alone but include the collection and processing of data, consultations and alignment, optimization and planning.

It is apparent from this description of industrial building that designers from various disciplines architectural designers, building physics designers, electrical and mechanical designers, construction designers and implementation designers - are involved in joint designing from an early stage.

\subsection{Design process study}

The trial module was designed in close cooperation by a team consisting of an employer, architect, structural engineer, fitter, contractor and representatives of the supply industry. An attempt has been made to describe the experiences gained through intensive participation in design meetings:

- The preparation for the meetings was limited to an agenda.
- Other subjects, such as planning, subsidy applications, composition of the design team, were also discussed.

- The fitter, in the capacity of installation consultant, aims to find quick solutions.

- The fitter discusses solutions a great deal.

- Little use was made of sketches in the concept design phase.

- Design problems were passed on to the subcontractors, who then solved them independently.

- Production costs were calculated in the traditional manner.

- Design problems were still being solved in the execution phase, usually at the building site.

During the building phase of the trial module, the meetings between the designers and the parties executing the work were sometimes reminiscent of a site meeting.

During the design and production process, a list of points for improvement was made, which could be used during a subsequent design process.

\subsection{Production process study}

The production process is considered a transformation of materials into a building, with waste as a by-product. The transformation is carried out by people and tools and managed using plans, drawings and instructions (monitoring). See figure 4.

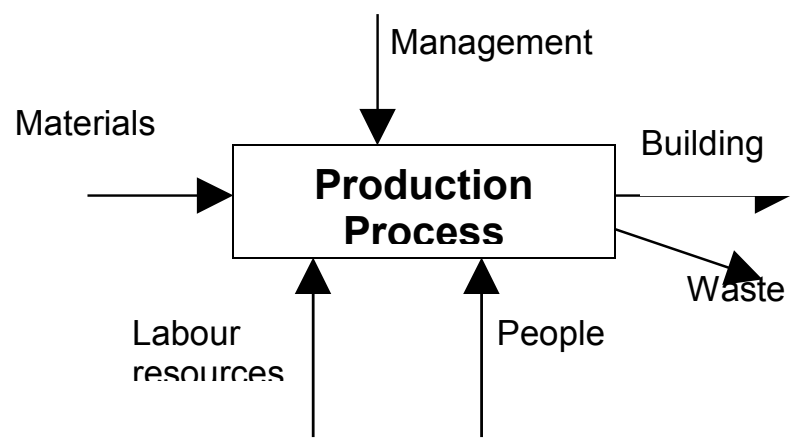

Figure 4. Model of the production process of a building.

The following aspects of the production process can be observed:

- The production process: preparation, transport, storage, treatment, processing, conditioning. 
- Materials, construction elements, construction components.

- The building and (separate) waste flows.

- The people: planners, project manager, supervisors, construction workers, mechanics.

- Labor resources: tools, scaffolding and accessibility structures, transport equipment.

- Management: planning, schedules, instructions, drawings.

The findings obtained during close monitoring of the production process at the plant and at the building site were recorded in a log, filmed or photographed. Explanations, comments and points for improvement are provided for photographs depicting extraordinary situations. Table 1 gives a concise overview of the findings and points for improvement for each aspect. [Van Gassel]

\section{CONCLUSIONS}

The following conclusions can be drawn after monitoring the design process and production process:

- In IFD building, the design process requires co-operation and a multidisciplinary approach. Matters such as design tasks, choice of designers, design tools and expected results must be considered during the course of the design process, and design meetings must be organized.

- Due to the lack of a suitable model to calculate the production, operating, renovation and demounting costs and the absence of a marketing plan, conventional design solutions are frequently chosen.

- The steel structure and floor panels are demounted very quickly. This is in contrast to the outer walls, roof, fittings and finishing elements.

- It is advisable to entrust one specific company with the responsibility for a number of production tasks, such as planning, making and checking the drawings, and allocating labor resources for transport and safety.

\section{RECOMMANDATIONS}

The IFD building system should be treated as a comprehensive product and be marketed by one company or a cluster of companies. The company or cluster of companies should develop an IFD cost model and marketing plan for this purpose. The marketing plan should address at least the following elements: living concepts, mass customization, adaptability at all phases of the building's economic life, period of use versus economic life, customer order release point, longrange production planning etc. Specific skills required for the organization and facilitation of and participation in design meetings could be obtained by a mutual exchange of knowledge.

\section{REFERENCES}

[Van den Brand] Van den Brand, G., Rutten, P., Dekker, K. 1999, IFD Bouwen, Principes en Uitwerkingen. TNO (Netherlands Organization for Applied Scientific Research) report 1999-BKRR021, TNO Bouw (Building and Construction Research) Delft.

[Bouwen op kennis] Bouwen op kennis, Rapportage verkenningscommissie Bouw, 2000, Adviesraad voor het Wetenschaps- en Technologiebeleid.

[Eekhout] Eekhout, Mick, 1997, POPO of ontwerpmethoden voor bouwproducten en bouwcomponenten, Delft University Press.

[Van Gassel] Van Gassel, Frans, 2001, Bijdragen aan de IFD Today systeemcatalogus. Report of the Eindhoven University of Technology.

[Hermans] Hermans, M, 1997, De marktpositie van IFD-bouwen voor de Nederlandse Bouwindustrie, Damen, Rotterdam.

[Hendriks 2001] Hendriks, Nico, Frans van Gassel, 2001, Construction of a prototype of an industrial, flexible and demountable (IDF) apartment building system. International Status Report on Aspects of FutureSite. CIB Publication 265, Wellington NZ.

[Hendriks 1999] Hendriks, Nico, 1999, Industrieel, Flexibel en Demontabel Bouwen (IFD): Ontwerpen op veranderbaarheid, Eindhoven University of Technology.

[IFD] IFD Today, 2000, Leaflet.

[Rutten] Rutten, P., Trum, H., 1998, Prestatiegericht ontwerpen en evalueren.

'Geïntegreerd ontwerp van gebouw en installaties', reader of the Eindhoven University of Technology. 
[SEV] SEV, Leaflet IFD and www.sev.nl

[Systeemcatalogus IFD Today] Internal IFD

Today publication.

Table 1. Findings and points for improvement with regard to the production process. 


\begin{tabular}{|c|c|c|}
\hline Aspects & Findings & Points for improvement \\
\hline Materials & $\begin{array}{l}\text { - Additional production space was needed } \\
\text { at the plant to mount technical } \\
\text { installations into the steel construction. } \\
\text { Mechanics had to determine reference points } \\
\text { and dimensions themselves as these were } \\
\text { not indicated on the drawings submitted. } \\
\text { - The production of large elements was } \\
\text { treated as a project instead of serial } \\
\text { production. } \\
\text { Mechanics frequently tried to mount } \\
\text { installations at the building site instead of } \\
\text { at the plant. } \\
\text { - Parts were selected and the assembly } \\
\text { order was determined at the building site. } \\
\text { - Small materials were delivered unsorted } \\
\text { and in bulk. As a result, much sorting was } \\
\text { needed and materials got damaged. }\end{array}$ & $\begin{array}{l}\text { - Special assembly drawings should } \\
\text { be made. } \\
\text { Investments should be made in } \\
\text { mechanization and robotization. } \\
\text { Construction components should } \\
\text { be coded. } \\
\text { Materials should be supplied in } \\
\text { crates and using additional means } \\
\text { of transport. }\end{array}$ \\
\hline Management & $\begin{array}{l}\text { Each supplier submits its own drawings. } \\
\text { Connections between construction } \\
\text { components of the various suppliers were } \\
\text { not provided and a solution had to be } \\
\text { found on site. Many telephone calls were } \\
\text { needed to obtain the required assembly } \\
\text { information. }\end{array}$ & $\begin{array}{l}\text { connections between the } \\
\text { construction components. } \\
\text { Specifications should be of a } \\
\text { quality that the need for drawings } \\
\text { and instructions is eliminated. } \\
\text { A project database and project } \\
\text { extranet should be used. }\end{array}$ \\
\hline People & $\begin{array}{l}\text { - Different types of scaffolding were } \\
\text { erected for different parts of the work. } \\
\text { Traditional safety provisions such as edge } \\
\text { protection were used. }\end{array}$ & 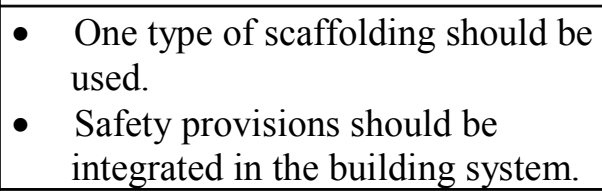 \\
\hline $\begin{array}{l}\text { Labor } \\
\quad \text { resource } \\
\mathrm{s}\end{array}$ & $\begin{array}{l}\text { Various types of cranes were used, } \\
\text { sometimes as many as four at the same } \\
\text { time. } \\
\text { Special labor resources were made and } \\
\text { deployed at the building site for the } \\
\text { purpose of the project. }\end{array}$ & $\begin{array}{l}\text { - One type of crane should be used } \\
\text { during the execution process. } \\
\text { - Specific labor resources should be } \\
\text { designed. }\end{array}$ \\
\hline Waste & $\begin{array}{l}\text { Much waste was produced during the } \\
\text { fitting-out process. } \\
\text { - Waste was not collected separately. }\end{array}$ & $\begin{array}{l}\text { - Returnable packaging should be } \\
\text { used. } \\
\text { Work on material carried out at } \\
\text { the building site should be kept to } \\
\text { a minimum. This should be } \\
\text { confined to the plant as much as } \\
\text { possible. } \\
\text { Waste should be separated in } \\
\text { accordance with government } \\
\text { regulations. }\end{array}$ \\
\hline Building & $\begin{array}{l}\text { Building physics measurements showed } \\
\text { that a number of details had not been } \\
\text { finished properly: noise leaks, air leaks, } \\
\text { etc. }\end{array}$ & $\begin{array}{l}\text { - Details should be finished } \\
\text { properly. }\end{array}$ \\
\hline
\end{tabular}

